\title{
3. Engendered Violence and Witch-killing in Simbu
}

\author{
Philip Gibbs
}

\section{Abstract}

Belief in kumo witchcraft has led and continues to lead to the gruesome deaths of many people in Simbu and elsewhere. This belief, whether real or imaginary, has consequences in thought and behaviour. Whether the victims are those killed by 'witches' or those accused of being 'witches', the suffering, death and social disruption are real. With reference to twenty cases, the paper seeks to shed light on the engendered nature of kumo witchcraft in Simbu. How true is it that women are much more likely than men to suffer this form of violence? Aside from direct violence, to what extent is the kumo phenomenon 'engendered'? Are traditional or contemporary gender relations a significant feature and, if so, how are such gender relations influenced by modernisation and other socioeconomic factors? It seems that Simbu people believe that males are more likely than women to die as a result of witchcraft. However, from the cases presented and the police and hospital records there is every indication that women are more likely to suffer violence as a result of being accused of witchcraft.

\section{Introduction}

Newspapers in Papua New Guinea (PNG) frequently carry headlines such as 'Sorcerers burnt alive' (National 2-4 May 2008: 1), 'Duo tortured, butchered and burnt' (National 5 February 2008: 3), 'Callous murder' (Post-Courier 10 January 2008: 1) or 'Woman "hanged" for sorcery delivers baby' (National 26 February 2008: 5). Most of these cases involve the brutal torture or killing of women accused of sorcery or witchcraft. ${ }^{1}$

An Amnesty International Report on Violence Against Women in PNG, which received considerable international publicity, reports the PNG Minister for Social Welfare Dame Carol Kidu as saying that although both men and women

1 I wish to thank the many people who contributed to this paper in sharing their ideas and experiences. For obvious reasons it is better that they remain anonymous. An earlier version of this paper appeared as: Witchkilling and engendered violence in Simbu, in Catalyst 40 (2010): 24-64. 
are targeted, women are reportedly six times more likely than men to suffer violence (Amnesty International 2006: 24). These forms of violence are described in the Amnesty International report as follows:

Often when a person within a community falls ill or dies unexpectedly, the community suspects that a curse or spell has been cast. The alleged sorcerer is identified, interrogated, tortured and often murdered in 'pay back' for the harm they are thought to have inflicted. The methods of torture used include beating (often with barbed wire), breaking bones, burning with red hot metal, raping, hanging over fire, cutting body parts slowly, amputating and pulling behind vehicles. If treatments of this kind do not result in death, often the victim is then killed by being thrown over a cliff, into a river or cave; burned alive in a house fire; buried alive; beheaded; hanged; choked to death, starved; axed or electrocuted; suffocated with smoke; forced to drink petrol or hot liquid, stoned or shot (Amnesty International 2006: 24).

The horrific list of torture and methods of murder is indeed correct, according to my enquiries. But is it correct to say that women are six times more likely to be subject to this violence? Dame Carol Kidu, when asked about the reference in the Amnesty International Report, replied that she does not recall making any statement about a six to one ratio of women to men, to Amnesty International or anyone else (Personal Communication, 27 Nov 2006). ${ }^{2}$ Yet Michael Unage and Patrick Kaiku have also suggested that five out of six victims of witchcraft execution are women (National 5 March 2008: 15; 6 May 2008: 18). ${ }^{3}$

Reports on these brutal killings focus mainly on the PNG Highlands or communities of Highlanders in coastal towns. Behind such violence, the principal motive is belief in kumo witchcraft in the Simbu Province, PNG. ${ }^{4}$ There are related beliefs in parts of the Western Highlands (Reay 1959: 138) and the Eastern Highlands (Newman, 1965). This paper seeks to shed light on the engendered nature of kumo witchcraft in Simbu. How true is it that women are much more likely than men to suffer this form of violence? Apart from the violence experienced, to what extent is the kumo phenomenon 'engendered'?

\footnotetext{
2 'I can't think why figures were attributed to me. I keep trying to remember the conversations I had with Amnesty International and the context and if I had heard anything at the time that I would have referred to in passing. However I cannot recall the details' (personal communication with Dame Carol Kidu, 27 November 2006).

3 Michael Unage also replies that he cannot now recall where he got that statistic from for the statement that five out of six victims of witchcraft execution are women (personal communication, 30 March 2009).

4 This is a peculiarity of parts of the Wahgi Valley, Simbu and the Eastern Highlands, because in other parts of the PNG Highlands, such as Enga and most of the Southern Highlands, people generally attribute death to the malevolent work of the spirits of the dead, not to spirit beings inhabiting the living. At Independence the Province was known as the Chimbu province; however, the Provincial Government now uses the term Simbu, which is becoming the accepted form.
} 
Are traditional or contemporary gender relations a significant feature and, if so, how are such gender relations influenced by modernisation and other socioeconomic factors?

\section{Witchcraft or sorcery?}

A search for the term 'sorcery' in the Post-Courier and the National daily newspapers between January and December 2008 shows eighty reports in which twenty-five refer to women sorcerers and seventeen to men as sorcerers. In thirty-nine reports the gender of the sorcerer is not specified (one report referred to both male and female sorcerers). Of the eighty reports, seven locate the sorcery in the Simbu Province and of those in Simbu all refer to women accused of sorcery, although one of these reports also included a male along with two women.

A search for the term 'witchcraft' in the same two papers from January to December 2008 revealed twenty-six reports. It is of note that all but five of these referred to witchcraft along with sorcery-usually in the expression 'sorcery and witchcraft'. The gender of the witch is mentioned in only two cases. In twenty-four out of twenty-six cases the gender of the witch is not specified. Simbu is mentioned in one report and in that case the reference is to a male. In nineteen out of twenty-six reports the place was not specified.

Table 1. Use of three terms in the Post-Courier and the National Daily Newspapers, Jan. to Dec. 2008.

\begin{tabular}{|l|c|c|c|c|}
\cline { 2 - 5 } \multicolumn{1}{c|}{} & Male & Female & Unspecified & From Simbu Province \\
\hline 'Sorcery' & 25 & 17 & 39 & 7 (all women) \\
\hline 'Witchcraft' & 2 & - & 24 & 1 (male) \\
\hline 'Sanguma' & 1 & - & 5 & 2 (1 male, 1 unspecified) \\
\hline
\end{tabular}

A search for the term sanguma in the same papers revealed six reports. In all but one, the gender is not specified and in the one case where it is specified it refers to a male, in Simbu. Simbu is mentioned in two cases and the other four leave the place unspecified. Such varied use of terms in the media calls for clarification on the use of terms in this paper.

Writing on witchcraft among the Azande in West Africa, Edward EvansPritchard (1937: 387) distinguished sorcery and witchcraft in terms of the former using techniques of magic, while the later uses hereditary psychophysical powers. Leonard Glick, writing on Papua and New Guinea, offers a similar distinction, 'A sorcerer's capacity to harm ... depends on his ability to control extrinsic powers; whereas a witch, who can inflict sickness or death 
on others simply by staring at them or willing evil on them, possesses powers inherited or acquired as an intrinsic part of his or her person' (1973: 182). Aside from the extrinsic/intrinsic distinction it is notable that Glick allows for both men and women as witches. This is in contrast to western imagery where the term 'witch' is strongly gendered as female. Garry Trompf (1991: 92-93) uses gender to distinguish witches (female) and sorcerers (male).

Heinrich Aufenanger, writing on the Central Highlands in the 1960s, considered witchcraft and sorcery together as 'an evil, supernatural power, which a man or a woman acquires from a bad, personal spirit or spirit-like being, and which he or she uses for asocial purposes, for doing harm to people and animals' (1965: 104). I will use Aufenanger's description of witchcraft in Simbu in this chapter.

The translation of indigenous terms into English can be complex. The Simbu themselves use the term sanguma, normally used in a wider context for assault sorcery, to refer to kumo witchcraft. ${ }^{5}$ Caspar Damien writes how 'In Simbu, sanguma is used to mean kumo and its evil activity .... Sanguma is used widely for kumo and has the same meaning in this context' (2005: 116). Damien is correct when referring to Simbu, however, because of the ambiguity of the term in other parts of PNG, this chapter will not utilise the term sanguma but rather the local Simbu term kumo or the English terms 'witch/witchcraft'.

Joachim Sterly notes how the Simbu do not hold kumo responsible for all unexpected deaths. He distinguishes malevolent spirits, sorcery and witchcraft in Simbu (1987: 87). The Simbu fear a multiplicity of super-powerful beings, which can bring sickness and death. For example spirits of the dead may punish people with insanity, constipation and body pains. There are also dingan 'demons' that appear in the form of earthworms dengreme amban and strike people with emaciation, kidney pains, blood in the urine and swelling of the private parts. Paula Brown notes the existence of potentially dangerous spirits in the mountains and bush, some able to be controlled and some not (1995: 29-30).

There are also practices of harmful magic - to be used against stealing from gardens, to punish a tardy debtor or to weaken an enemy before a fight. The Simbu know about lethal sorcery as it is manifest elsewhere in New Guinea, including their neighbours on the Madang side of the Bismarck Range, but it is not part of their own traditions. Sterly notes how people feared a Simbu sorcerer who obtained his magical spells and accessories from the Ramu as gifts in the bride-price process, and brought them into the upper Simbu, yet they did not equate such sorcery with their own kumo (Sterly 1987: 96). ${ }^{6}$ When a witch gives

5 For a discussion of the various meanings and derivation of the term sanguma, see McCallum 2006.

6 Sterly notes that it is not possible to completely demarcate the two realms from each other, because both magic and witchcraft go on in a context of magical powerfulness (Sterly 1987: 87). 
someone something to eat with evil intent, what kills that person is the kumo, not the food. The source of harm in kumo is a creature residing within the witch while magical forms of harming and killing are practical procedures, sometimes involving occult power.

\section{Kumo witchcraft}

Kumo refers to a malevolent power said to take the form of a creature such as a rat, bat, frog, snake, or flying-fox (usually a nocturnal creature), with the power to kill or harm people. The kumo creature lives within the body of its host, the so-called kumo-person kumo yomba. Individuals who have kumo are variously called kumo yagl (kumo man), kumo ambu (kumo woman) and kumo gage (kumo child). Kumo is said to be passed from parent to child or grand-parent to child and runs in families. However, it can also be passed to an unsuspecting or curious person who touches a kumo-person on the head or hands. ${ }^{7}$ The recipient starts to feel different and soon realises that he or she is controlled by a being within them - a being that calls them their new 'father' or 'mother'. Kumo are said to be able to fly and to pass through walls or doors. While the kumo person sleeps at night, the kumo creature can take human or other form and roam at night, eating human waste and searching for human flesh, particularly vital organs like the heart or liver (Damien 2005: 128). ${ }^{8}$ The movement of kumo at night may be traced by moving lights (said to be similar to fireworks) - 'witches torches' (kumo ken).

Traditionally it was believed maladies caused by kumo included infections of the liver (munduo nongwa), inflammation of the lungs (munduo mongungwa), bloody diarrhoea (dem boromai sungwa), or unusual swelling of the body (nangie yakungwa) (Sterly 1987: 90). However, Aufenanger notes that 'nearly always when there occurred a death, people thought, kumo was the reason for it' (1965: 104). Even today any form of death may lead to kumo accusations. Moreover, kumo may be linked to accidents such as when a person is injured falling from a tree or in a traffic accident. The victims of witches are regularly those of their own clan, and mostly relations inside the same hauslain (sub-clan). Sterly notes the case of a woman accused of killing her own son. Other close relatives threatened with, or thought to be killed by kumo include husbands, in-laws, nephews, grandchildren and brothers and sisters (1987: 85).

\footnotetext{
7 Women accused of kumo witchcraft are seldom if ever raped, perhaps because to do so would expose a man to the kumo creature which some say can reside in a woman's genitals.

8 If the kumo roaming at night (usually in the form of an animal) would be killed, then the kumo person sleeping at home would die also. Also, the kumo dies when its 'mother/father' - the kumo person - dies; hence the practice of killing accused kumo persons.
} 
No one knows for sure who is a kumo person, as they live in the community just like anyone else in the village. Suspects are accused during funerals, perhaps with reference to some form of 'strange' behaviour such as staring at people or having been seen wandering aimlessly at night. Another significant factor is suspicion that the accused may have had a grudge against the deceased. A confession may be forced through threats and torture, but whether they confess or not, the accused are often killed or banished from the community.

Sometimes communities enlist the help of a kumo 'doctor' or 'witch doctor' to identify the culprit. A kumo 'doctor' is a 'retired' kumo person who has declared that he or she will not practise kumo for malevolent purposes. I have spoken with retired kumo persons about their understanding of the kumo creature and they seem to be reluctant carriers. ${ }^{9}$ One elderly woman told me how her kumo creature (taking the form of a rat) entered her body when she was a young woman. ${ }^{10}$ She claims that she didn't like having the kumo creature, which would go around doing 'bad' things, but, although the creature was not totally independent, there was often little she could do about it. She observed that her kumo creature was becoming thin and weak, just like her. A young man who acts as a kumo doctor referred to his kumo creature as 'nature.' He had learned to control it as he was not happy with the 'bad' things that his kumo creature would do. He said that at times he sent the creature away but it would return to him. Being a kumo 'doctor' is a recognised occupation and the practitioner is paid, sometimes handsomely, for the exercise of his or her profession.

The reader can learn more about kumo from publications on the topic including those by Heinrich Aufenanger (1965), John Nilles (1950), Paula Brown (1964), Joachim Sterly (1987) and Casper Damien (2005). The principal issue to be addressed here is whether gender relations are a significant factor in kumo witchcraft.

\section{Traditional gender relations in Simbu}

In the Kuman language the term ambu means 'woman'. The word carries with it connotations of weakness and inferiority. There is a common conception that women are physically weak, powerless, helpless and dependent on men for

\footnotetext{
9 Sterly gives an account - originally from Heinrich Aufenanger - of a woman who tricked her own kumo creature (a bat) so that it would emerge and she could kill it by stabbing it with a knife and then throwing the head into the fire (Sterly 1987: 67).

10 In order to prove that she was a kumo person and to be recognised as a kumo 'doctor' she had brought what she claimed was human flesh to the Kundiawa hospital for the hospital authorities to confirm as human flesh, but she did not receive a response. She is not yet officially recognised as a kumo 'doctor.' This was the only case I heard about where someone asked the hospital to confirm that flesh was human. It is certainly not a normal requirement.
} 
security and support. One hears expressions from men such as 'Ambu yombugln ta pai kurma yoko moglo' ('You, woman, have no strength so be quiet') or 'Ambu yomba we digua motna yoko moglo' ('You are just a woman so keep quiet and do not talk'). Girls hear such denigrating expressions from an early age and are encouraged to behave accordingly.

The Kuman term yagl means 'man', but also signifies strength, power, superiority and independence. One hears expressions such as 'Yagl makan sugl yomba meglkua' ('Men are the inheritors of their fathers' land'), 'Yagl ka kaugo yomba meglkua' ('Men are the public speakers'), or 'Yagl kunda yomba meglkua' ('Men have the power to enter into war and solve disputes'). Both young men and women hear such expressions as part of the socialisation process.

Traditionally, women's lives were associated with looking after pigs, raising children, gardening and household duties. Men were rather more focused on constructing houses and defending the interests of the clan. Men distanced themselves by living separately in the men's house, usually public and located on high ground. In public events men did the talking while women took the back stage and remained spectators. In the domestic context women ensured that the fire kept burning and that their husband, children, pigs and dogs were fed every day. Wife beating was defended as an appropriate way of disciplining women since the woman had been procured through 'bride price'. A woman was expected to attend and mourn at funerals lest she be suspected of being implicated in the cause of the person's death. ${ }^{11}$ Most of these gendered roles and expectations continue in people's lives today, despite modernisation and social change. Women often have a say in the domestic sphere since they are the ones who tend the gardens, raise the pigs and children. It is in the public arena where the well-being of the clan is at stake that men typically assert power over women.

Yet, the traditional configuration of gender relations was an ideal that was not always strictly adhered to. There were cases where physically powerful women took on men's roles in fighting, and daughters of prominent village leaders or war heroes were sometimes allowed to live in the men's house and play the sacred flutes (kua) normally reserved for men. An old woman recalls, 'When I was a young girl, my father used to bring me to the men's house and I lived with my father and my tribesmen in the men's house. In the men's house my grandfather used to teach me how to play the flute.'12 There are also cases in Simbu where men took on what were considered women's roles: remaining silent in public forums, tending to sweet potato gardens and looking after pigs.

11 Women play a more prominent role in grieving at funerals, but men are also expected to participate (carrying large pieces of firewood and the like).

12 She adds, "They just said, "Ogoyagle orko Andeyagle orko orma kondo"' (K: She is a woman but she is gifted by the great grand-father spirit in the sky so let her alone) (personal communication 10 April 2009). 


\section{Changing relationships}

Traditional notions still influence ideals of gender relations in Simbu today. However, Simbu society has experienced major changes, at first with colonial and mission influence, and in recent decades since PNG independence with modernisation and ongoing global influences. Traditional initiation rites and courting ceremonies have disappeared. Husband and wife share the same house; boys and girls attend school together and in the weekends take part in sporting events followed by social evenings and movies.

Most old men who went through initiation or who married after traditional courting and bride-price ceremonies claim to have found a balance in gender relations within marriage. ${ }^{13}$ Older women too generally accept the roles and responsibilities expected of them, including child rearing, gardening, cooking, cleaning, looking after animals, welcoming guests and attending funerals. Amongst older people, gendered differences are accepted and there is little competition.

However, many younger people are unsettled. Money plays an ever-increasing role in relationships, and there has been a commoditisation of bride-price payments. Young unmarried women feel pressure to bring income for their family either through bride price, finding employment, or marrying a man with money. Education is seen as a way out of village life and if they are forced to leave school because of lack of school fees, many women will go from one relationship to the next. Unemployed, unmarried young men spend much of their time looking for cash necessary to attend socials, picture shows, or to obtain homebrew and marijuana. They feel that they have to compete with women and many are angry with their female counterparts, who prefer men with money. They claim that girls look down on them as mere drakbodis or stimbodis (derogatory Tok Pisin terms referring to them being drug addicts and useless). Unemployed young men say that marriage is a 'mistake' - in the sense that unintentionally getting a girl pregnant obliges him to take her as his wife whether or not he feels capable of supporting her and the child.

Today men reluctantly concede that women can do almost everything that their mothers had never even thought of doing. Some women now contest for elections, deliver public speeches, take an active role in public gatherings, drive cars and run businesses. There is a gap between commonly held beliefs about gender and actual practice. Men are said to be the head of their family, yet a substantial number of men let their wives handle family finances because the women are often better at budgeting. It is said that women do not wear trousers and if they do-particularly the 'pocket' variety - they risk being raped, yet

13 Writer's interviews with men at Goglme, Genai and Gaglmambuno 20 September-3 October 2008 
today the majority of younger women do wear trousers. These developments pose a threat to men's social dominance. Men have to compete with women in ways that were unheard of before. Some men admit to feeling frustrated and envious as a result. Unemployed young men who say they have left school due to the lack of school fees feel angry and let down, many seeking solace in homemade liquor and marijuana. 'They don't smoke marijuana or drink home brew for nothing - they do it out of frustration. ${ }^{14}$

A number of people have admitted that negative feelings, especially when combined with intoxicating substances, can lead to aggressive and violent reactions towards others, especially towards women and girls. Village leaders admit that they can do little to control the behaviour of youth today. 'Many don't listen to us. They just do what they want. Then when they feel hungry they steal from someone else. This is what is happening and it is destroying the community.' ${ }^{15}$

\section{Witch killing in pre-colonial and colonial times}

Who were the witches and how were they treated in pre-colonial and colonial times? The first contact of Simbu people with the outside world occurred with the arrival of the Leahy brothers and the first Catholic and Lutheran missionaries in 1933. Heinrich Aufenanger, a Catholic priest and an ethnologist from the Anthropos school, researched Simbu witchcraft in the period between 1934 and 1961. He tells how he saw a would-be kumo woman killed with a broad double-edged arrow in her chest. In another case a young man had shot at his own mother. On yet another occasion a mother of several small children just escaped death after an arrow had lifted up the skin of her chest (Aufenanger 1965: 114). In the first part of his paper Aufenanger provides five examples and it is notable that in all cases the suspected kumo persons were elderly women and all the 'victims' of kumo were male. Writing during Australian rule prior to PNG Independence he notes how in former days such women would be killed, but 'now they are merely dismissed because the government does not allow this kind of punishment any longer' (1965: 109-10). Murder, whether of accused witches or anyone was discouraged by the harsh rule of the colonial kiap (TP: government officer), however the writer has only anecdotal evidence and no reliable data to determine whether witchcraft accusations actually decreased during the colonial period.

\footnotetext{
14 'Em ol $i$ gat wari o $i$ gat as tingting na ol smok. Ol i no smok na dring stim nating, ol i gat wari ya' (TP) (middle-aged man, 21 September 2008, Goglme).

15 'Planti tru em ol $i$ no harim tok bilong mipela. Ol i stap long laik bilong ol. I go go na ol hangre nau em ol $i$ go stilim kaikai bilong narapela man. Mipela tok liklik long ol, em ol i no harim. Ol mekim dispela pasin i stap olsem na long komyuniti bilong mipela i bagarap na bagarap olgeta' (TP) (older man, 22 November 2008, Waingar).
} 
However, the following nine examples from elderly people in Simbu recalling events from their younger days in colonial or pre-colonial times offer suggestive evidence of past patterns. ${ }^{16}$

Case 1. A middle-aged widow was accused of killing one of her in-law's sons through kumo. She was dragged from her house, tortured and thrown into a cave where she died. No one came to her aid because it happened in the night and this woman had no brothers to support or defend her. Her deceased husband too had no brothers who could come to her aid. It seems that the men who accused her were angry because they had wanted to marry her after the death of her husband, but she had refused.

Case 2. Two blood relatives quarrelled over a plot of vacant land. Two weeks later one man's daughter became ill and died. Some men accused the wife of the other relative of kumo and killed her. When the husband tried to support her they killed him as well. People suspected that the quarrel was a motive for killing the girl. The couple that died had no children to support them. Even the husband had no blood brothers to support them. They were tortured and killed and their bodies thrown into a cave.

Case 3. There was an ugly bachelor whose parents died when he was small. He tended to isolate himself, not coming to the men's house. Despite his ugliness he was known for his skill in hunting. He would return from hunting trips laden with possums that he would share with those living nearby. Other men became envious of his hunting skill. One time after a feast an old man died. People accused the bachelor of killing him with kumo and the men shot him with an arrow. They dragged him back inside his house and set fire to the house so that he burnt to death. His parents were dead and he had no other family members to support him.

Case 4. There was a tribal fight and one of the young warriors was shot in the abdomen and died. During the funeral some of the men went out to relieve themselves and noticed an unusual light on the other side of the river. The men mobilised themselves and secretly went to that place with their bows and arrows to find out who was lighting a fire on such a night. On arrival they did not find a fire, but rather an old married couple in a house. Because of the light they had seen, the men immediately suspected the old couple of kumo. They set fire to the house and burnt the couple alive. The couple had no sons, only three daughters who had already married out to other places.

Case 5. During a pig-killing festival a woman argued bitterly with a male relative saying that she was not receiving enough pork. A month later the man with

16 These cases were recorded in the Kerowagi District with the help of a Kuman-speaking researcher during the month of June 2008. 
whom the woman had quarrelled fell ill. The son of the sick man tried to heal the broken relationship by giving a large pig in the hope that she would remove whatever was making his father ill. However, the sick man's condition got worse and he died. The son ordered the relatives not to cry. He got his spear and went to the woman's house and speared her to death. He also tried to kill her husband but missed and the husband escaped to his uncle's place. The couple had one son who also ran away and joined his father in their uncle's place. They never returned for fear that the angry son would kill them.

Case 6. During a food festival the two wives of one man argued over the amount of food they had received. The community was in favour of the first wife because she was customarily seen as the legitimate wife of the husband. After two months the only son of the first wife became ill and died. Because of the quarrel that the two wives had had some time before, the people thought the second wife, who was dissatisfied over the food during the food festival, had killed the boy with kumo. However they did not harm her because she had four sons who were strong and very aggressive. The people were afraid to attack the woman lest the four sons would retaliate and fight back.

Case 7. A woman who was a relative of the deceased came to mourn at a funeral. When she entered her crying sounded strange-more like shouting than crying. This unusual behaviour raised suspicion in people's minds that she was not really sorry and that she might be a kumo person who had caused the man's death. After the burial the villagers, especially the men, accused the woman, tied ropes round her neck and threw her over a cliff and she died. The woman was married and had a son and a daughter, but they could do nothing to defend her. Her husband took his son and daughter, left the village and went to live elsewhere.

Case 8. A very old man told how when he was young he had a girlfriend in another village. One time he visited her place for a courting ceremony but he found the place deserted. He remained quietly in a corner of the house. All of a sudden his girlfriend and her mother entered the house carrying meat, which to the young man looked like human flesh. He ran for his life to the nearest men's house to report what he had seen. The men promised they would burn the women and have the father and son killed as well. A few days later he heard that his girlfriend's house had burned, and later heard that her father and brother had been shot to death. (The person giving the account felt that perhaps the girl had refused to marry this man, so he made up the story about human flesh, knowing that it would most likely result in her being suspected of being a kumo person.)

Case 9. An old man in his seventies told how in his early years he had adopted a young girl. The girl often stayed out-presumably sleeping at the homes of 
other people. After a while her unsocial behaviour upset the man and led him to believe that she might be a kumo person. One day he prepared a good meal and invited her to come. While she was there he told her that they would go for a feast in another village and that she should wear her best traditional attire. They set out for the next village which was on the other side of a river. When they came to the middle of the bridge over the flooded river he came up behind the girl and pushed her into the river and she drowned.

The nine cases above reveal a pattern similar to that noted by Aufenanger. Of the nine cases, eight of the suspected kumo persons were female. The one male accused was an ugly bachelor who did not frequent the men's house-and so did not conform to dominant models of masculinity. In six out of the seven cases where the kumo had killed someone, the 'victim' was male. We might also note that in a majority of cases the accused person had little or no defence and in the case where the woman had strong sons, people were afraid to attack her lest her sons retaliate. Several men died, but in all cases except one the men were not the principal kumo agent, but rather husbands, sons, or brothers of a female kumo person. In several cases tense relationships leading to suspicion of kumo had to do either with jealousy or with arguments over food distribution. In former times the killing was done in secret without the public humiliation and extended torture that accompanies accusations of kumo witchcraft today.

\section{The victims}

Discussions about kumo witchcraft reveal divergent opinions as to just who are the 'victims'. Some consider the victims to be those who suffered the direct effect of acts of witchcraft. Most of these victims are dead. Others consider the victims to be those who have been accused of being witches. Most of these have been tortured and many are dead. Others have suffered but survived torture and abuse. Still others have fled their homes and gone to survive in other provinces. The identification of 'victims' in this situation thus depends on how one considers violence and the reality of witchcraft.

When the term 'violence' is used, it is necessary to consider who is labelling a given act as such. In Simbu, the people apprehending, torturing and killing a 'witch' often consider themselves to have done something meritorious, ridding their community of yet another threat. ${ }^{17}$ The apparent moral propriety of the act would lead many to consider it acceptable and legitimate. The core purpose is to protect the community from the perceived threat of witchcraft. It is the actions

17 Laura Zimmer-Tamakoshi (Ch. 2) describes how Gende sorcerers demand compensation for ridding the village of a person who is seen as a threat to the community. 
of the witch which are rather seen as unacceptable and illegitimate, thus calling for radical measures amounting to self-defensive homicide. All of this depends on how people understand the reality of witchcraft.

Belief in and fear of witchcraft are obvious in Simbu. However, one must distinguish the empirical (verifiable) from non-empirically real (believed) and the real from the imaginary. Some things may be considered real though not verifiable (e.g. a quality such as love). Many aspects of Simbu witchcraft appear incapable of empirical verification which is imputed from its effects. For example, it is said that the kumo comes in the form of an animal residing in the body of the witch, that the kumo kills by eating internal organs of the victim, that there is a 'parliament' of witches located within Mt Elimbari in Simbu, and that witches now resort to modern means such as the use of a 'kumo gun' or 'kumo helicopters'. It is difficult to subject such beliefs to empirical analysis. Simbu people themselves sometimes look for verification by having the 'witch' kill a chicken from a distance. It seems that witchcraft is real to those who believe in it.

Both the perception of violence and the belief in a phenomenon like witchcraft need to be taken seriously. Kumo is certainly 'real' in its consequences and to insist on asking whether it is verifiably real is to risk dismissing its social reality in favour of a presumption of the real as empirically verifiable. Whether the victims are those killed by witches or those accused of being witches, the suffering, death and social disruption are real. This belief has real consequences in thought and behaviour. Belief in kumo has led and continues to lead to the gruesome deaths of many people in Simbu and elsewhere. The wider society in PNG is starting to confront the reality of such suffering. A recent newspaper editorial quoted Judge George Manuhu as saying, 'Such deaths are a very long way indeed from traditional and customary methods of punishment of those who break traditional and customary laws. ... It may be that the time has come to regard murder as murder, without the subtleties of sub-definitions common in other societies' (National 24 July 2008). In April 2009 the Constitutional and Law Reform Commission established a working committee to review the law on sorcery and sorcery-related killings in Papua New Guinea.

The National newspaper, in an editorial, has raised the issue of how there can be so many cases of witchcraft-related violence in a so-called Christian country (National 29 February 2008: 24). Some churches interpret kumo as a form of spirit possession or demonic deception (Bartle 2005: 247-55; Johns 2003). Sometimes, however, recognising evil power as real may only confirm accusers in their belief and practice. The Catholic Diocese of Kundiawa takes a different approach with an eight point pastoral plan, emphasising pastoral presence in communities where people have died, and also care for the accused. The diocese has a policy that those who accuse others of being witches and who are involved 
in abusing, torturing or killing are excluded from the sacraments and the active life of the church until they give compensation, are reconciled and restore the good name of the accused.

\section{Victims of witches}

One needs to distinguish two different scenarios for becoming a victim. The first is the death of a person through some form of illness or accident. In Simbu these are often thought to be the victims of witchcraft. The victims in this case are predominantly male. The second scenario is the torture and/or death of a person accused of being a witch. The victims accused of witchcraft are predominantly female.

Cases 1-9 above were from pre-colonial and colonial times. The seven cases below are from incidents in recent years.

Case 10. An elderly widowed woman was accused of witchcraft after a boy died and people remembered that she had been looking for lice in the boy's hair shortly before he became ill. ${ }^{18}$ Under torture she admitted to participating in killing the boy, but also accused another woman of joining her in the act. In doing so, she was claiming not only to be a witch but also to be a witch 'doctor', who could detect other witches. People did not believe her, so to prove that she was a witch she produced some flesh which she claimed was human flesh taken from a grave. She says that the flesh was sent to Kundiawa hospital for examination, the hospital did not release the results. Since that time she has left her community and lives in Kundiawa town, spending time at the hospital with her disabled son and with relatives.

Case 11. A brother and sister, both in their late fifties, were accused of kumo witchcraft after the death of a local boy. The brother had found that the boy had killed his chicken and discovered him eating it. Naturally he was unhappy about this. Shortly afterwards the boy got sick and died. (The boy had been visiting his brother in the coastal town of Lae and the medical report says that he died from malaria.) The dead boy's relatives accused the elderly brother and sister of being responsible for this boy's death. Both were tortured and killed. People claimed that the sister was surely a witch because she had been seen doing strange things, such as removing her intestines to clean them in the river. The brother's two sons were away at the time. Those responsible for killing the

18 In an interview at Kerowagi a local leader referred to her case and independently confirmed the details of her story. 
couple say they were not aware that the boy had died of malaria until the report was read out to them later. Upon hearing this they paid compensation of money and pigs to the two sons of the deceased couple.

Case 12. A popular, thirty-nine-year-old married woman, with three children and excellent gardens, got very upset about her husband going around with other women. Finally she committed suicide by drinking Gramoxone herbicide. After her death some young men, close relatives of her husband, claimed that she died of kumo witchcraft. These young men then accused and tortured people from several families. Some of the families fled to other places. Three of those accused and tortured badly were an elderly man and his wife and their only daughter. The man was not originally from the village, but came there as a school teacher who taught Tok Pisin. Eventually he and his family were chased out of the village and their land and property were taken over by their accusers. Afterwards the father of the woman who had committed suicide came and forcefully demanded compensation for her death. There was no compensation for the man and his wife and daughter, or for any of the others who were threatened and fled, losing their land and possessions.

Case 13. A widow in her forties had two children, one living in Port Moresby and one, a young man, staying with her. Two of her brothers had died. After her husband died her brother-in-law wanted to marry her but she declined, preferring to live alone with her son. Later a young man died, after returning from schooling on the coast. It is likely that he died from malaria. However relatives of the young man accused her of causing the death of the student through kumo witchcraft. When interviewed in Kundiawa hospital she felt that some people might have been jealous of her for having good, productive gardens. When interviewed two years later she told how she had found out that men had initially accused another woman, but her brother-in-law had told the other woman that she would be released if she would accuse the widow instead. ${ }^{19}$ She has now left her husband's village and lives with her mother in her home village. Her son uses part of her land in her husband's village, but part has gone to those who assaulted her.

Case 14. A young man with a university degree and a good job died in a coastal town. His body was brought back to Simbu and during the funeral, a group of young men, led by a brother of the deceased, came accusing a forty-fiveyear-old woman of having worked sanguma on the deceased when she gave him a sweet potato to eat. They dragged her out of the house and tortured her by thrusting heated iron rods into her vagina and into her abdomen. The grieving family were in the mourning house. Other women were afraid and ran

19 After partially recovering from her horrific injuries there was a court case in which she was awarded compensation of K20,000 and fifteen pigs, which, after two years, has not been paid. 
away. Some of the village leaders tried to intervene but they were powerless. The woman was a church leader. She would not admit to being a witch and told them that she was prepared to be crucified as Jesus had died. She was a widow-her husband having died in a tribal fight. She had no children of her own but had two adopted sons who were too young to defend her. The woman was also a 'mother' to the young men who did the killing, as they were her husband's brothers' sons. She died and they buried her in a shallow grave in a place used as a toilet.

Case 15. A young man who had been a seminary student died in Kundiawa hospital-most probably from cancer. After his death, some relatives of the dead young man's mother accused the two older brothers of the young man's father and their wives of causing his death through kumo witchcraft. Neither of these families had any children of their own but had adopted children. One of the wives was killed and her body thrown into a pit toilet. The two brothers and the remaining wife fled. People claimed that it was not a coincidence that one of the brothers and his wife hosted a celebration for bride-price exchange in the village on the very day that the young man died in Kundiawa hospital, and that this was a sign that they were to blame for the young man's death.

Case 16. A high profile male public servant died in Simbu and relatives were accused of 'Sorcery' (Post-Courier 23 September 2008: 6). One night during the funeral a woman was hit over the head with a piece of firewood and dragged unconscious towards the village cemetery. She was never seen again. A witness notes, 'Although the house was filled to capacity with people, nobody dared to stand or do something. It happened all of a sudden like lightning. I presume everyone was dumbfounded' (Witness report - Police files). That same night the woman's husband and his other wife were also accused and attacked. 'They started chopping, cutting, kicking, punching, hitting us with sticks and stones. My wife and I were helpless. They set fire to my house and screamed, "Sanguma! (TP) Cut their throats and throw them into the toilet!"' (Report - Police files). The two were interrogated and taken to the Wahgi River, where, however, a magistrate intervened; pointing out that the accused man was a village leader. So they were not thrown into the river. I spoke with the two later when they were recovering from their serious injuries in Kundiawa hospital.

Cases 10 to 16 show characteristics similar to those observed in the earlier cases. All 'victims' of witchcraft were male. In all six cases women were accused of causing the deaths through witchcraft. All were widows or elderly and none had children capable of defending them. In cases 11, 12, 15 and 16, men were also accused. However, the men were accused along with a woman and in the case of the brother and sister (case 11) it seems that people had more 'evidence' of his sister having been seen participating in witch-like behaviour (cleaning her intestines in the river). The two men in cases 11 and 12 were not prominent 
men but marginalised, with no one to defend them. The brother and his sister in case 11 were both old and living together on their own. The other man was an immigrant from another village. In case 12, the man and his wife and daughter were not killed but permanently ostracised. The two brothers in case 15 had no children of their own. The land of those killed or banished in case 13 was taken over by the accused. In case 16 a woman was killed, but her husband's life was spared because he was a village leader. Unlike in former times when killing would be done quickly and in secret during the night, and by authoritative figures, the torturing or killing in cases 10 to 16 was a lengthy process, occurring during the day, and was carried out mostly by groups of young men.

Joachim Sterly, observing kumo cases during the 1970s and 80s, appears to have witnessed a similar pattern with regards to the victims of witchcraft.

From what I have seen the victims of kumo are more often children and men than they are grown women. It is often said that the kumo people who want to take revenge on other adults 'strike' the children of these people. But it is hard to say why more men than women fall victim to the kumo. Is it that kumo women deliberately avoid harming those of their own sex? (1987: 85).

It is hard to know whether Sterly is correct in speculating that kumo women avoid harming those of their own sex, however, based on my own much more recent enquiries, it appears that it is indeed women who provoke harm to other women by accusing them of being witches. A number of informants, both male and female, agree with Aufenanger (1965: 112) that it is women, usually older women, who first start talking about kumo. 'The women are behind the accusations with their gossip, so women first talk about witchcraft and the men listen and take the lead in assaulting the accused. ${ }^{20}$ Why would a woman want to start talking about another woman and witchcraft knowing that it might lead to the death of that woman? A suggested reason given is that knowing that there is a very good chance that it will be a woman who will end up being accused, getting in first to focus suspicion on someone else is a form of self-defence. 'The woman will raise the topic of witchcraft and will influence her husband. She will accuse another person of witchcraft and her husband will talk with others and then go and do violence to the person who they think is the witch.'21

\footnotetext{
20 'Ol meri em as bilong sutim tok na tok baksait so ol meri save go pas tok sanguma na ol man bilong ol save harim na take lead na paitim ol manmeri long sanguma' (TP) (young married woman, 6 June 2007, Goglme).

21 'Meri em bai olsem tokim man bilong em long pasin sanguma na samting olsem kamap long haus, na em bai sutim bel bilong man bilong em na em bai tok olsem em dispela manmeri save wokim sanguma na man bilong em bai go na tokim ol narapela na ol bai paitim dispela man or meri husait ol i ting olsem em sanguma' (TP) (interview with young adult male, 8 July 2007, Kerowagi).
} 


\section{Victims as accused witches}

As well as this collection of cases that I have assembled, quantitative data is available from an investigation of police and hospital records in Kundiawa, the provincial capital of the Simbu Province.

\section{Police records}

Police records (2000-2007) with the Homicide Office in Kundiawa, record 121 persons accused of being witches and killed or badly abused, and complaints being laid with the police. Of these people, seventy-three were killed and fortyeight escaped death, though often with terrible injuries. The police report that they were beaten, burned, shot or chopped with axes or knives. Of these accused, sixty-one (50.4\%) were women and sixty (49.6\%) men. Of those who died, thirty-seven were women and thirty-six men. Most were older or elderly people in the forty to sixty-five age bracket. ${ }^{22}$

\section{Hospital records}

Hospital records (1996-2005) with the Kundiawa hospital, presented to a Melanesian Institute Symposium in 1996 by Dr Joe Aina, revealed that fortynine cases admitted were a result of the injuries suffered after having been accused of witchcraft. Of these people admitted to hospital three died. The rest somehow recovered from their terrible injuries. Many were suffering from burns over much of their body and some had deep cuts, to the extent they had to have limbs surgically amputated. Sixteen (33\%) were male and thirty-three $(67 \%)$ female. Again, most were older or elderly people in the forty to sixty-five age bracket.

Another study of entries in the Admissions books for the Surgical ward at Kundiawa hospital (1992-2006) revealed forty patients identified as 'Sanguma Cases'. (It was a practice that the nurse would enter a note as a comment in the

22 Police action could be traced in 87 of the 121 cases. Action on these 87 cases is as follows:

Convictions: 28 cases

Pending investigation: 19 cases (some go back as far as 2001)

No lead: 19 cases

Solved out of court: 11 cases

Pending: 4 cases

Withdrawn: 2 cases

Suspects in Moresby: 3 cases

Suspect escaped: 1 case 
admissions book at the time.) Of these twenty-five $(63.5 \%)$ were female and fifteen $(37.5 \%)$ male. Again, most were mature or elderly people in the forty to sixty age bracket, with some simply marked as 'advanced age'.

Table 2. Data from the Kundiawa Police, Hospital and Surgical Ward Records.

\begin{tabular}{|l|c|c|}
\cline { 2 - 3 } \multicolumn{1}{c|}{} & Female & Male \\
\hline Kundiawa Police Records & $61(50.4 \%)$ & $60(49.6 \%)$ \\
\hline Kundiawa Hospital Records & $33(67.0 \%)$ & $16(33.0 \%)$ \\
\hline Kundiawa Surgical Ward & $25(63.0 \%)$ & $15(37.0 \%)$ \\
\hline
\end{tabular}

\section{Male witches}

From the data above it appears that a substantial number of men are victims of being accused of witchcraft. Almost half the victims reported to the police are male. More than half these males (37) had died, their mean age being forty-one years. Also at least one third of those appearing in hospital records are male. Sterly notes, 'It is true that in the nearby Asaro and down at Bundi that kumo is classed as woman's sorcery but in Simbu it is exercised by men as well and can be directed against women' (Sterly 1987: 85). ${ }^{23}$ In the cases discussed so far most of the accused men have either been elderly or marginalised or both. However, four cases (17-20) below are examples where strong men in highprofile positions have been accused of witchcraft.

Case 17. The accused was a village councillor in Simbu. As councillor he was a prominent leader in his village. In 2006 the wife of his younger brotherwho had a job with a good salary - died from an unidentified illness. Some people suspected that the councillor's wife might be behind the death. They apprehended her and tortured her. The councillor was accused of having got kumo from his wife and he too was accused. His house was burned and property destroyed and he was sent out from the village. The councillor had a brother and a son, but both were afraid to support him lest they too be accused.

Case 18. The case of a village magistrate is related to case 17 above. As a magistrate he occupied an important position in the community. After the death of the young woman, some people went around looking for possible culprits. They apprehended the magistrate's daughter. Under duress she told them that she, her mother and the wife of the councillor had planned to kill the young woman because she had not given them money. Angry young men hung the women from trees and tortured them, but did not kill them. The magistrate and

23 Patterson notes how among the Gururumba of the Eastern Highlands both men and women may be witches, but only women are ever accused (Patterson 1974: 145). 
his wife and daughter fled from the village, abandoning their land and leaving their possessions behind. The magistrate has three brothers but they were afraid to intervene lest they suffer the same fate.

Case 19. A young man died and the wife of a policeman was accused of causing the death through kumo. His wife was tortured by a group of angry young men. The policeman tried to intervene to support his wife, but was accused also and forced to flee with his wife and daughters. They now live elsewhere, but he maintains that they were falsely accused and that one day he will return to his village to reclaim his land and coffee gardens.

Case 20. This refers to case 16 above. One of the accused was a prominent village leader. Most of his sons were not present at the time he was attacked by the mob and the one son staying with him escaped during the night to seek help, through the back window of the house. One of the leader's wives has disappeared and is presumed dead. The other wife was so badly injured that she had to spend several months in hospital. The leader is pursuing the matter through the court system.

In the four cases above, one of those who died was a young man, another a high profile male public servant and the other a young woman with a good job. By earning a salary she was not an average woman but had a high status in the community due to her education and more importantly, because of her wages and the money she brought into the community. In all cases it was initially women who were accused of being witches and the men accused were husbands or fathers of the women. The women were tortured but the men - all with high status or with the capacity to bring money into the community-were not killed. Some were ostracised and had to leave their land and possessions and go to live elsewhere.

\section{Engendered violence?}

The data given above from the police and hospital records appear to raise doubts about assertions noted at the start that women accused of sorcery or witchcraft are six times more likely than men to suffer violence. However, they are suggestive of certain engendered patterns of violence around kumo witchcraft.

It does appear that women are more likely to be targeted than men. The term for 'kumo person' in the Kuman language used around Kundiawa is kumo ambu- 
which is feminine. ${ }^{24}$ The masculine form kumo yagl can be used but it is not so common. The ratio of men and women in police records could be biased because, as one woman noted, 'Women are unimportant, so don't merit the trouble of bringing the police in on the case. ${ }^{25}$ Others have voiced similar views about the status of women and their having less chance of their cases being reported to the police. Hospital records show that women are twice as likely to end up in hospital after such violence. This ratio could also reflect a bias if men would generally have more means by which to reach a hospital.

On the other hand, one sees in cases 12 and 17 to 20 that some men were not tortured or killed. Their lives were spared, although some were sent away from the village. Such cases would most likely not appear in police or hospital records, thus suggesting bias in a different direction.

Nevertheless the larger question remains as to the engendered nature of kumo witchcraft. Two factors linked to gender relations will be considered here: women marrying in from outside and contestations about status.

\section{Women marrying in}

Mervyn Meggitt (1964), accepting Kenneth Read's view of antagonism pervading inter-sexual encounters throughout the Highlands, correlated variations of sexual antagonism with the degree of hostility existing between affinally related groups, the presence or absence of men's purificatory cults and the social status of women. His main point was that where hostile groups inter-marry there is a likelihood of antagonism between the sexes. Such a situation may well have influenced the exogamous and predominantly virilocal marriage arrangements in Simbu. Paula Brown has refined this argument for Simbu, suggesting there were hostile clans yet friendly affines (Brown 1964). John Nilles (1950: 49), describing the separation of the sexes amongst the Kuman of Simbu, tells how men keep secrets from women in order to keep them in subordination and that for a woman to dare learning these secrets would be to risk being killed.

In Simbu the majority of women move to join their husbands when they marry. Thus the married woman, particularly with bride-price exchange, is indeed accepted into the clan, but never achieves the same identity with the clan as her husband. Sterly notes how 'the kumo men live on their own land among their blood relatives, while witches, once married, are strangers to where they live. ... Their only blood relationship is with their own children' (Sterly 1987: 141-

24 People find it difficult to answer the question as to whether kumo is male or female. One person suggested that all kumo must be female because they can reproduce themselves to be passed onto another person. 25 'Ol meri ol $i$ no important so ol ken $i$ dai nating na ol no inap long reportim kain case long police' (TP) (interview with young married woman, 6 June 2007, Goglme). 
42). During tribal warfare men suspected that women might bring information to support the woman's brothers in the opposing clan. A similar dynamic could apply to women when the clan is perceived as being threatened by witchcraft. Despite friendly affines, suspicion could fall on women who marry into the clan rather than on the clan's own men, who trace their clan identity back through ancestral links. People would be particularly suspicious if the woman comes from a family with a history of kumo witchcraft. When women accuse other women of witchcraft at funerals, they will have come from different in-marrying clans. One cannot expect women's solidarity in such a precarious situation.

\section{Status}

One must be careful not to presume that women are merely of lower status. Sterly comments that 'no woman in Simbu society will be despised precisely for being a woman, even if she is a witch' (Sterly 1987: 141). Sterly associates the lower status of women with their coming into the community from outside as affines. Whatever the reason, males tend to claim exclusive right to leadership - a factor which influences witchcraft accusations. In all but two cases, those said to be killed by witches were male - the death of a male being thought, according to tradition, to be a greater loss. In the two cases above in which witchcraft accusations came after the death of women, both were women of high status in the sense of providing leadership and bringing resources into the communityone a successful thirty-nine-year-old woman with excellent gardens (case 12) and the other an educated young woman earning a wage (cases 17 and 18).

Status associated with gender also appears as a factor in who will be accused. In the cases given above it is women, particularly widows or the elderly, who are targeted. We do not have sufficient information from the police and hospital data to be able to assess from those sources the status of those who were presumed to have died of witchcraft or those who were accused of witchcraft. However, in a recent example from Simbu, people said they did not even bother to accuse anyone over the death of a young woman (who died of cancer) because she was 'useless', having been involved with several men but without marrying and consequently not bringing bride price to the family. As I have noted in another publication, people often feel ashamed when it is thought that a family member dies from AIDS, so they are buried quickly without time for discussion about kumo witchcraft (Gibbs 2009). Stigma and discrimination associated with AIDS locates an infected person very low on the social hierarchy.

\section{Socio-economic factors}

Socio-economic factors and modernisation are also at work. Often people use the Tok Pisin term jelas to describe a motive for witchcraft accusations. The 
meaning of jelas goes beyond the English term 'jealous'. To be jelas is to be in a state of desiring something held by another. Wardlow glosses the term as 'uncontrollable, angry desire' (2002: 8). Unlike Wardlow's Huli 'wayward women', who embody the modern woman taking control of her economic power, even with hazardous results, the Simbu witch represents traditional culture rather than modernity and an accusation renders one powerless. Where the Huli woman goes through a form of social death to become modern, the Simbu witch faces physical death as a consequence of the angry desire (jelas) of others in the clan. Inevitably when a person is accused of witchcraft and they are killed or flee, their house and possessions are stolen or burned and their food gardens and coffee plots taken over by their accusers. There is a shortage of good agricultural land in Simbu, and with the breakdown of postpartum sex taboos, and better health facilities, there are more surviving children to provide for than before. When in a jelas state one could fight over land and possessions but perhaps to accuse another of witchcraft and take over their land is a more socially acceptable alternative.

Moreover, witch 'doctors' and diviners are paid well for their work of identifying those responsible for sickness and death. Divination is a lucrative job, and there is also the temptation to accuse others falsely just to get one's hands on the money.

\section{Power and the powerless}

Witchcraft is the mystical powers in the possession of those usually found at the bottom of the social hierarchy' (Unage 2008: 29). ${ }^{26}$

Engendering in Simbu witchcraft is not just an issue of gender relations, but also power relations. Women are outsiders marrying into the clan. There are clear differences of status and power deriving from both traditional and modern sources. A common scenario is becoming the victim of jelas sentiments. This all points to powerlessness as a significant factor in witch killing in Simbu.

Torturing and killing accused witches is an act of power, not of status seeking. Women are unanimous that those executing the accused (mostly young menoften under the influence of alcohol or marijuana) are not considered heroes in a way that tribal fighters are heroic. Tribal fighting requires bravery, whereas the people we interviewed recognised that in killing witches a whole group gangs

26 Michael Unage, National 12 March 2008: 29. For discussion on power, sorcery and witchcraft, see Zelenietz 1981: 3-6. 
up against one person, which is not heroic at all. Some young women said that seeing men act so violently makes them less attractive as potential marriage partners.

Women are more likely to be accused of witchcraft because of their weaker social and political presence. They are disadvantaged physically, socially and ideologically. Women, particularly older women can hardly defend themselves from physical attack by an angry mob. A woman generally does not have the same social status in the clan as her husband or her sons. Ideologically women were and are regarded as weaker, inferior and dependent on men. Despite modernisation and social change, ideals and expectations derived from tradition continue to influence gender relations today. So, when a family, believing that death comes through human agency, looks for a scapegoat to accuse, fingers will very often point at a woman without influential brothers or strong sons.

Women tell of their feelings of total powerlessness when they are accused of being witches. Recently I conducted surveys in several clans in Simbu asking about who had died in the past year and the perceived cause of these people's deaths. ${ }^{27}$ In some cases, elderly women were accused of being witches and tortured even before a person had died. In several cases men were seriously ill in hospital and women were waiting back in the village with a death sentence hanging over their heads. People had told them that if the man in hospital died, their funeral would be at the same time as his. It could be that they were being threatened with the intention that they would somehow reverse the power of witchcraft, thus allowing the patient to recover, but I am more inclined to think that such threats fit in with a pattern of scapegoating and accusing people of occult powers, and only those people who at the same time had no physical power to defend themselves. One woman put it this way, 'I couldn't speak. I felt totally powerless when they called me a witch. All fingers pointed at me and everyone stared at me. ${ }^{\prime 28}$ Another woman said, 'I live here and people think I am a witch. My immediate reaction was to feel ashamed and I felt like drowning or hanging myself. They beat me and it hurt me deep inside and I just cried.' ${ }^{29}$ The

\footnotetext{
27 In the survey of clans asking about the perceived cause of death, the underlying cause in most cases was witchcraft, even though a person may have died in an accident, a tribal fight or from a recognised medical ailment such as cancer or malaria. For example, a young boy died of an intestinal complaint and parents and relatives of the boy accused an old woman of witchcraft because the day before his death the boy had said 'thank you' to the woman as she passed even though they had not seen her give him anything. It was presumed that her kumo spirit must have given him something which caused his death.

28 'Mi nogat pawa bilong toktok. Olgeta strong na powa ol kisim pinis taim ol $i$ kolim mi sanguma. Olgeta pinga na olgeta man i lukluk long mi' (TP) (interview with middle aged woman, June 2008, Kerowagi).

29 'Mi bai slip kirap long dispela ples ol man bai glasim mi olsem sanguma. Na mi skelim kwiktaim insait long mi $i$ stap laip yet na kisim sem na i laik kalap long wara o hangamap long rop. Na ol paitim mi long en em mi pilim dispela insait tru long lewa bilong mi na mi krai tasol na mi stap' (TP) (interview with elderly woman, April 2009, Papnigl).
} 
same woman continued, saying that as they tied her and tortured her she felt powerless and thought of her daughters who were married in other parts of the province and of her young son who was too small to defend her.

Young men today in Simbu view it as almost an obligation to avenge the death of a family member through accusing and torturing or killing some person thought to have been the cause of the death. One young man put it this way, 'The boys were very angry because of our father's death. It is bad to lose a father and my mates felt sorry for me. They were not concerned about doing right or wrong. We thought we were doing the right thing because a witch had killed our father. We would be happy if we killed the witch.' ${ }^{30}$ For these young men violence is a justifiable response to an act that threatens the well-being of the clan.

How is it that some of the accused were able to live to tell of their experience? My survey of recent deaths reveals that the accused survived or were released when police (who were not family members) were called to the scene or where a strong church leader was present to remind people that for Christians in the modern world there are alternatives to witchcraft. In effect it means that if sufficiently motivated to act, the power of the police and civil authorities or the power of the church can be enough to defend a person who is otherwise powerless.

A Simbu Catholic theological student tells how he attended a funeral of a family friend. The Mingende hospital staff had said that the cause of death was heart failure. Nevertheless as part of the mourning process the sons of the deceased saw it as their role to ask 'who' was behind the death of their father, and to accuse women of witchcraft. However they noticed that the theological student was among the mourners and thought that it would offend him if they would assault a woman among the mourners. So they declared, ' $\mathrm{X}$ is here and we don't want to upset him, so you sangumas are safe.' They then made some general statements and warned the 'sangumas' not to kill again. ${ }^{31}$ This is not an isolated case, as a number of church workers have related similar stories.

The sons of the deceased believed that there were powers of witchcraft active within the community responsible for death and misfortune and that they had a responsibility to take an aggressive and violent stand against that power. The irony of witch killing in Simbu is that the one accused of occult power is most often physically or socially powerless. Sometimes village leaders give their direct

\footnotetext{
30 'Ol bois $i$ belhat nogut tru bikos em $i$ kilim wanpela papa bilong mipela. Lusim papa bilong mi em $i$ samting nogut tru na ol wan-skwad bilong mi ol $i$ sori long mi. Ol i no wari ol i mekim rong o nogat. Mipela $i$ ting olsem samting mipela i mekim em $i$ rait bikos em bin sangumaim na kilim wanpela papa bilong mipela. Mipela bai amamas sapos mipela $i$ kilim em $i$ dai' (TP) (son of deceased, April 2009).

31 Gabriel Kuman, 'Sorcery, Witchcraft and Development in Papua New Guinea.' Unpublished manuscript, 2009.
} 
or tacit approval to killing and torturing those accused of witchcraft. However even if they would want to stop the violence they have little power today in the face of a village mob - particularly when many young men within the mob are affected by alcohol or drugs.

\section{Conclusion}

Richard Eves (2006) writes about violence against women and how many men see their manhood as dependent on their power over women and use violence to achieve this. Could it be that young men thus seek to validate themselves in the eyes of the community and their peers? Other scholars perceive male violence against women to be fuelled by male resentment over women's gains in economic and social independence (Zimmer-Tamakoshi 1997) or humiliation over women's refusal to abide by personal obligations (Wardlow 2005). Surely feelings of dependence, resentment and humiliation figure in the violence directed against those accused of witchcraft in Simbu. However, I am of the opinion that an equally significant motive comes from a sense of loathing and fear, thinking that a person who harbours a kumo creature has killed a family member and may kill again. Thus violence against accused witches differs from that of rape and domestic violence. Suspects will be people identified as marginalised, appearing to act strangely, as harbouring a grudge against the person who has died or is dying and as someone who cannot retaliate. Most often the person fulfilling those criteria is a woman. Those doing the accusing, who may be men or women, are looking for a scapegoat-someone to blame.

It should be noted that while young men play a leading role in hitting, torturing or killing the accused, women too might participate in the violence. 'It wasn't just the men who beat the three witches. The women too took up stones and sticks to hit them. Old and young women together were involved in accusing and hitting the three. ${ }^{32}$ Other women express different sentiments. They would like to help but feel powerless. 'They were just killing helpless people.' ${ }^{33}$

How true is it that women are much more likely than men to suffer this form of violence? From the cases presented it appears that Simbu people believe that males are more likely than women to die of witchcraft. However, from the cases given and the police and hospital records there is every indication that women are more likely to suffer violence as a result of being accused of witchcraft. But, apart from the incidences of the death and injury to both victims, to what

32 '... i no ol man tasol involve long paitim ol dispela tripela sanguma manmeri, ol meri tu involve na kisim ston na stik na paitim ol dispela tripela lain. Ol lapun na yangpela meri olgeta ol involve long paitim na krosim ol dispela tripela lain'(TP) (interview with middle-aged woman, 1 July 2007, Goglme).

33 From interview with middle-aged woman, 1 July 2007, Goglme. 
extent is the kumo phenomenon 'engendered'? Traditionally women were regarded as weaker, inferior and dependent on men. Despite modernisation and social change, the ideals and expectations deriving from tradition continue to influence gender relations today. Women are still vulnerable as outsiders who marry into the clan, particularly if they have 'only' daughters or if they do not have mature strong sons. If a woman has large flourishing gardens that others might envy or if she stirs up bad feelings by refusing to marry she may well generate bad feelings that lead to her being a candidate for blame at the death of a relative. Moreover, women have to cope with other women pointing a finger at them in self-defence. Most men do not wish to see their wives, daughters or sisters treated so violently, but in Simbu they realise that they too might be accused of being partners in witchcraft and suffer the same fate. So often such men remain as powerless witnesses or they absent themselves when mob rule takes over.

The tragedy of kumo witchcraft today is exacerbated by the deterioration of law and order at the community level. Who has power and authority these days to bring justice, order and stability to communities? The 'bottom' of the social hierarchy becomes even more insecure as social norms and practices break down or become dysfunctional. Changing ingrained cultural attitudes and practices associated with witchcraft will require far more than teaching people scientific, verifiable explanations for sickness, death (Zocca 2008: 58). It also requires a multidimensional approach to developing a cultural coherence where antisocial behaviour associated with alcohol and drugs is an exception; where there is trust rather than mistrust within families; where there is a collective response to protect the powerless, so that society can be a safe place, rather than a place where fear and powerlessness persist in the face of the terror of witchcraft.

\section{References}

Amnesty International, 2006. Papua New Guinea: Violence Against Women: Not Inevitable, Never Acceptable. AI Index: ASA 34/002/2006. Online: http://www.amnesty.org/en/library/info/ASA34/002/2006/en. Accessed 20 January 2011.

Aufenanger, Heinrich, 1965. Kumo, the deadly witchcraft in the Central Highlands of New Guinea. Asian Folklore Studies 24(1): 103-15.

Bartle, Neville, 2005. Death, Witchcraft and the Spirit World in the Highlands of Papua New Guinea: Developing a Contextual Theology in Melanesia. Goroka: Melanesian Institute for Pastoral and Socio-Economic Service Inc.

Brown, Paula, 1964. Enemies and affines. Ethnology 3(4): 335-56. 
1972. The Chimbu: A Study of Change in the New Guinea Highlands. Cambridge: Schenkman.

1977. Kumo witchcraft at Mintima, Chimbu Province, PNG. Oceania 48: $26-29$.

1995. Beyond a Mountain Valley: The Simbu of Papua New Guinea. Honolulu: University of Hawai'i Press.

Damien, Casper, 2005. The myth of Kumo: knowing the truth about Sanguma in Simbu Province. Catalyst 35(2): 114-34.

Evans-Pritchard, E., 1937. Witchcraft, Oracles and Magic among the Azande. Oxford: Oxford University Press.

Eves, Richard, 2006. Exploring the Role of Men and Masculinities in Papua New Guinea in the 21st Century: How to address violence in ways that generate empowerment for both men and women. Report for Caritas Australia. Online: http://www.baha.com.pg/downloads/Masculinity\%20and\%20 Violence\%20in\%20PNG.pdf. Accessed 28 November 2010.

Gibbs, Philip, 2009. Sorcery and AIDS in Simbu, East Sepik and Enga. Occasional Paper no. 2, Port Moresby: National Research Institute.

------- 2010. Witchkilling and engendered violence in Simbu. Catalyst 40(1): $24-64$

Glick, Leonard, 1973. Sorcery and witchcraft. In Anthropology in Papua New Guinea: Readings from the Encyclopaedia of Papua and New Guinea, ed. Ian Hogbin, 182-86. Melbourne, Carlton: Melbourne University Press.

Johns, Vic, 2003. Sanguma and the power of the Gospel in reference to the Gumine People (Simbu People). Melanesian Journal of Theology 19(1): 46-76.

Kuman, Gabriel, 2009. Sorcery, witchcraft and development in Papua New Guinea. Unpublished Manuscript, viewed at the Melanesian Institute, Goroka, PNG.

McCallum, P. Maurice, 2006. 'Sanguma' - tracking down a word. Catalyst 36(2): 183-207.

Meggitt, Mervyn, J., 1964. Male-female relationships in the Highlands of Australian New Guinea. American Anthropologist, New Series 66(4) Part 2: 204-24, New Guinea: The Central Highlands.

Newman, Philip, 1965. Knowing the Gururumba. New York: Holt, Rinehart and Winston. 
Nilles, John, 1950. The Kuman of the Chimbu Region. Oceania 21: 25-40.

1953. The Kuman people: a study of cultural change in a primitive society in the Central Highlands of New Guinea. Oceania 24: 199-220.

Patterson, Mary, 1974-5. Sorcery and witchcraft in Melanesia. Oceania 45: 13260, 212-34.

Read, Kenneth, 1965. The High Valley. New York: Colombia University Press.

Reay, Marie, 1959. The Kuma. Melbourne: Melbourne University Press.

Sterly, Joachim, 1987. Hexer und Hexen in Neu-Guinea. München: Kindler Verlag.

Trompf, Garry, 1991. Melanesian Religion. Cambridge: Cambridge University Press.

Unage Michael, 2008. National. 12 March, 29.

Wardlow, Holly, 2002. Headless ghosts and roaming women: specters of modernity in Papua New Guinea. American Ethnologist 29(1): 5-32.

2005. Transformations of desire: envy and resentment among the Huli of Papua New Guinea. In The Making of Global and Local Modernities in Melanesia: Humiliation, Transformation and the Nature of Cultural Change, ed. Joel Robbins and Holly Wardlow, 57-72. Aldershot, Hampshire: Ashgate Press.

Zelenietz, Marty, 1981. Sorcery and social change: an introduction. Social Analysis 8: 3-14.

Zimmer-Tamakoshi, Laura, 1997. 'Wild pigs and dog men': rape and domestic violence as 'women's issues' in Papua New Guinea. In Gender in CrossCultural Perspective, ed. Caroline B. Bettell and Carolyn F. Sargent, 538-53. New Jersey: Prentice Hall.

Zocca, Franco, 2008. Sorcery, witchcraft and Christianity worldwide and in Melanesia. In Sorcery, Witchcraft and Christianity in Melanesia, ed. Franco Zocca and Jack Urame, 10-20. Melanesian Mission Studies no. 5. Goroka: Melanesian Institute. 